Article

\title{
Qualitative evaluation of antibacterial and DNA binding activity of four local ethnomedicinal plants available in Barishal, Bangladesh
}

\author{
Mahmudul H. Suhag ${ }^{1 \mathrm{a}}$, Md. Uzzal Hossain ${ }^{2 \mathrm{a}^{*}}$, Sohel Ahmed ${ }^{3}$ and Md. Nazmul Kayes ${ }^{1}$ \\ ${ }^{1}$ Department of Chemistry, University of Barishal, Barishal-8200, Bangladesh \\ ${ }^{2}$ Department of Botany, University of Barishal, Barishal-8200, Bangladesh \\ ${ }^{3}$ Department of Chemistry, Shahjalal University of Science and Technology, Sylhet-3114, Bangladesh
}

${ }^{\mathrm{a}}$ Mahmudul H. Suhag and Md. Uzzal Hossain contributed equally to this work

${ }^{*}$ Corresponding author: Md. Uzzal Hossain, Department of Botany, University of Barishal, Barishal-8200, Bangladesh. E-mail: muhossain@bu.ac.bd

Received: 23 July 2020/Accepted: 20 August 2020/ Published: 30 September 2020

\begin{abstract}
Screening of antibacterial activities of plants due to secondary metabolites is an authentic basis to look for a new drug. As a result of increasing demand for traditional treatments, scientists have look forward to search the efficacy of these so called ethnomedicinal plants and have to exchange with pharmacologists. An initiative of this, the antibacterial activity of Eclipta prostrata (L.) Mant. Azadirachta indica A. Juss., Aloe vera (L.) Burm. f. and Catharanthus roseus (L.) G. Don was studied against Escherichia coli and Staphylococcus aureus. Among four ethnomedicinal plants subjected to test antibacterial activities, Eclipta prostrata was found to act against both strains of bacteria whereas Azadirachta indica was effective against Escherichia coli only. DNA binding affinity of these medicinal plants was also studied by viscometry. No affinity between each medicinal plant extracts and isolated human cheek cell's DNA was observed.
\end{abstract}

Keywords: ethnomedicinal plant; antibacterial activity; DNA binding; viscometry; human cheek cell; Barishal

\begin{abstract}
1. Introduction
Bangladesh, specially Barishal has rich floral diversity of traditional ethnomedicinal plants and the traditional medical system which is several hundred years old including Unani and Ayurveda. Besides, from time immemorial primitive people living in close contact about utilization of ethnomedicinal plants by way of trial and error. World health organization (WHO) has estimated that $80 \%$ of the world population depends on traditional herbal medicines (WHO, 2001). Physiologically bioactive compounds are contributed from medicinal plant species for the remedy of numerous ailments (Adebanjo et al., 1983; Natarajan et al., 2005) which are infectious or non-infectious. As a consequence of sharing this resource of knowledge from one generation to next without any written documents, it is getting lost day by day. So, it is essential that the knowledge now available among local and tribal people to be documented and integrated with modern scientific values before it gets lost in Bangladesh.

Synthetic antibiotics discovered in the twentieth century can treat only of the infectious diseases. However, due to the incessant use of these antibiotics over the years, pathogens have become resistant to synthetic medicines (Ahmad and Beg, 2001) as a result of bacteria's genetic ability and mutation. Thereby, herbs have been emphasized as traditional medicines containing medicinal ingredients because of their curative potentiality (Bhalodia and Shukla, 2011); thus they are used in the further development of drugs. Majority of plants species in different locations around the world have been examined for their pharmacological properties and they are distinguished to possess numerous secondary metabolites such as flavonoids, steroids, tannins, terpenes, saponins (Kamali and Myel, 2010; Lalitha et al., 2010; Sen and Batra, 2012) and different investigations have been published on describing the pharmacological properties. Antibacterials of plant origin have immense therapeutic potentials and are effective in the treatment of infectious diseases than synthetic antimicrobials
\end{abstract}


which have adverse effects (Brandi et al., 2006). Out of the total 225000 plants species, only less than $10 \%$ have been studied so far for their medicinal properties (Widjaja and Lester, 1978; Kelmanson et al., 2000). The practice of complementary and alternative medicinal treatment is now increasing in developing countries in response to World Health Organization (WHO) directives and has provided the scientific basis for the effectiveness of traditional medicinal practices. The role of traditional medicines in the solution of health problems is invaluable on a global level and as a result, research on medicinal plants has intensified and information on these plants has been exchanged worldwide. Moussaoui et al. (2016) studied the antibacterial activity and synergistic effect between antibiotics and the essential oils of some medicinal plants. Furthermore, the combination of essential oils of plants with antibiotics was found effective against the emerging microbial drug resistance. Cagri-Mehmetoglu et al. (2017) studied the antibacterial properties and minimum inhibition concentration of Microdesmis puberula, Hypoestis verticillaris, Icacina tricantha, and Enterolobium cyclocarpum against 21 different bacteria and reported the antibacterial activity and phenolic contents of four medicinal plants of Nigeria. Meghla et al. (2016) studied the antibacterial activity of some medicinal plants against Escherichia coli, Salmonella spp. and Staphylococcus aureus. Valle et al. (2015) studied the antibacterial activities of ethanol extracts of Philippine medicinal plants against multi drug resistant bacteria. Valli et al., (2014) also studied the anti-inflammatory, analgesic and DNA binding studies of manjanathi fruit extract. They reported that manjanathi fruit extract have a binding affinity to calf thymus DNA.

Therefore, in this study the antibacterial effect of the Ethanol extract of Eclipta prostrata, Azadirachta indica, Aloe vera and Catharanthus roseus were studied against Escherichia coli and Staphylococcus aureus as Uddin et al. (2017), Hossain and Rahman (2018), Alam and Haider (2018), Das et al. (2013) reported these species as ethnomedicinal plants along with high citation frequency, fidelity level and available in University of Barishal campus as wild, exotic and cultivated. So the objectives of present study are to find out the modern scientific basis of antibacterial properties by disk diffusion method in which the diameter of inhibition zone is directly proportional to bacterial susceptibility (Suhag et al., 2014). In addition, binding between DNA from human cheek cells and plant extracts was performed by viscometric analysis to find out the interaction.

\section{Materials and Methods}

\subsection{Collection of plant specimens}

The plants i.e. Eclipta prostrata, Azadirachta indica, Aloe vera and Catharanthus roseus had been collected from their natural habitat, from different locations of University of Barishal, Bangladesh. The plant specimens were identified and authenticated in the Department of Botany, University of Barishal, Bangladesh (Figure 1) using standard literature (Ahmed et al., 2008-2009). Then the plant specimens had been subjected to ex-situ conservation at the net house of mentioned University for future uses.

\subsection{Preparation of extraction}

Collected medicinal plants leaves were washed with tap water, ethanol and distilled water; and dried in sunshine and at oven $\left(50^{\circ} \mathrm{C}\right.$ temperature). Then the dried samples were ground by mortar and pestle (Meghla et al., 2016; Ramchandran et al., 2012). The conical flasks were sterilized in the oven for 1 hour. $5 \mathrm{~g}$ of powder from each of the samples was poured into the conical flask. Following this, $50 \mathrm{~mL}$ of ethanol (Merck, Germany) and $50 \mathrm{~mL}$ of methanol (Merck, Germany) was added to each flask separately and gently mixed it perfectly. Then solutions were shook for 3 days at room temperature at orbital shaker (Model No-JSOS-300). The preparation of each solution was repeated and kept for 3 days at static conditions at room temperature. The extracts were filtered, centrifuged and evaporated (Meghla et al., 2016; Ramchandran et al., 2012) and were kept for further uses.

\subsection{Collection of bacterial strain}

Isolated pathogenic bacterial strains of Escherichia coli and Staphylococcus aureus were collected form Popular Diagnostic Centre and Hospital, Sylhet. The collected strains were incubated in an incubator (Model No-Binder RL-53) and inoculated on sterile, analytical nutrient agar medium and stored at $4^{\circ} \mathrm{C}$ until further use.

\subsection{Study of antibacterial activities}

Antibacterial activity of medicinal plants was studied by the disk diffusion method (Suhag et al., 2014; Bell et al., 2009). At first nutrient broth medium was prepared by beef extract (Sigma-Aldrich, India), yeast extract (Sigma-Aldrich, India), peptone (Sigma-Aldrich, India) and $\mathrm{NaCl}$ (Sigma-Aldrich, India) in distilled water and autoclaved for 15 minutes. Then a single colony of Escherichia coli and Staphylococcus aureus bacteria was added in $20 \mathrm{~mL}$ broth separately and incubated at $37^{\circ} \mathrm{C}$ for 24 hours. After that, a stock solution of $50 \mathrm{mg} \mathrm{mL}{ }^{-1}$ was made by dissolving ethanol extract of medicinal plants in distilled water. $10 \mu \mathrm{L}$ of stock solution (500 $\mu \mathrm{g}$ 
sample) was socked in each sterilized filter paper (Whatman, 0.45 micro pore) disk of uniform diameter ( $5 \mathrm{~mm}$ ) and thickness $(1 \mathrm{~mm})$. Then $25 \mu \mathrm{L}$ of activated bacterial solution was placed onto the surface of an agar plate (agar plate was prepared by $35 \mathrm{gL}^{-1}$ of bacteriological nutrient agar) with the help of micropipette with sterilized tips and spread evenly over the surface by using a sterilized bent glass rod. Finally, sample disks and antibiotic disks of ciprofloxacin (CONDA, Spain) were applied in freshly prepared agar plates and incubated at $37^{\circ} \mathrm{C}$ for $24 \mathrm{~h}$. The zone of inhibition (diameter) was then measured (in $\mathrm{mm}$ ) around the sample and standard antibiotic disks. Antibiotic ciprofloxacin (CIP) was used as a standard antibiotic disk to make a comparison with plants extracts. The antibacterial results of the extracts were compared with the standard antibiotic.

\subsection{Isolation of DNA}

DNA was isolated from human cheek cells by general salt extraction process (by using sodium chloride and detergent solution), purified by chloroform and precipitated in ice-cooled ethanol (Garbieri et al., 2017). Purity of DNA was evaluated by a UV-Vis spectrophotometer (Lamda-365).

\subsection{DNA binding studies}

The qualitative viscosity experiments were carried out by using Ostwald viscometer at room temperature. The relative viscosity of solutions was measured at a fixed concentration of DNA $(25 \mu \mathrm{M})$ and different concentrations of plant extracts $(50-500 \mathrm{ppm})$ with respect to pure DNA solution $(25 \mu \mathrm{M})$ in water (Ramachandran et al., 2012 and Prasad et al., 2011).

\section{Results and Discussion}

\subsection{Extraction of medicinal plants at different physico-chemical conditions}

Medicinal plants were extracted by ethanol and methanol separately. It was observed that extracted ability of ethanol to medicinal plants is significantly higher than methanol. Plants were also extracted at static and shaking conditions separately. It was observed that negligible amount of extracts were found at static condition. So plant extracts by ethanol at shaking conditions have been chosen for antibacterial and DNA binding studies.

\subsection{Antibacterial activity}

Antibacterial activity of experimental medicinal plants was tested against Escherichia coli and Staphylococcus aureus and compare with antibacterial activity of antibiotics ciprofloxacin (CIP) against corresponding bacteria. Azadirachta indica showed highest zone of inhibition against E. coli among ethanol extract of Eclipta prostrata, Azadirachta indica, Aloe vera and Catharanthus roseus. Besides this, both of the bacterial strain showed highest susceptibility and resulted a landmark zone of inhibition against standard antibiotic disks named ciprofloxacin (Table 1; Figure 2A, 2B; and Figure 3). Detail description for each specific plant species are:

\subsubsection{Eclipta prostrata}

This medicinal plant species showed both gram-positive and negative reactions against Staphylococcus aureus and Escherichia coli respectively showing almost the same diameter of inhibition zone (Table 1 and Figure 2A, 2B; Figure 3A and 3B). Rahman and Rashid (2008), Kaisar et al. (2011), Ripa et al. (2012), Uddin et al. (2010) reported the antibacterial properties of this species against different of both gram-positive and gram-negative bacterial species including $E$. coli and $S$. aureus.

\subsubsection{Azadirachta indica}

Only gram-negative reaction has been observed against $E$. coli. But no antibacterial properties against $S$. aureus had been seen (Table 1; Figure 2A and Figure 3C). Islam et al. (2012) reported the antibacterial properties of this species against different of both gram-positive and gram-negative bacterial species including $E$. coli and $S$. aureus but the plant extraction was prepared in Hexane, Butanol.

\subsubsection{Aloe vera}

Both of the bacterial strains showed no antibacterial activity (Table 1). Molla et al. (2010) reported the antibacterial properties of this species against different strain of both gram positive and gram negative bacterial species including E. coli and S. aureus with ethanol extracts but minimum inhibitory concentration (MIC) was many times higher than ours. 


\subsubsection{Catharanthus roseus}

No antibacterial activity for both E. coli and S. aureus (Table 1) was observed. Molla et al. (2010) reported the antibacterial properties of this species against different of both gram-positive and gram-negative bacterial species including E. coli and S. aureus with ethanol extracts but MIC was many times higher than ours.

\subsection{DNA binding studies}

The binding of four experimental medicinal plants extract to the DNA was investigated by viscometric studies. It was observed that there is no significant increase in the viscosity of DNA on the addition of plants extracts, which indicates that there were no binding interactions of DNA with these medicinal plants.

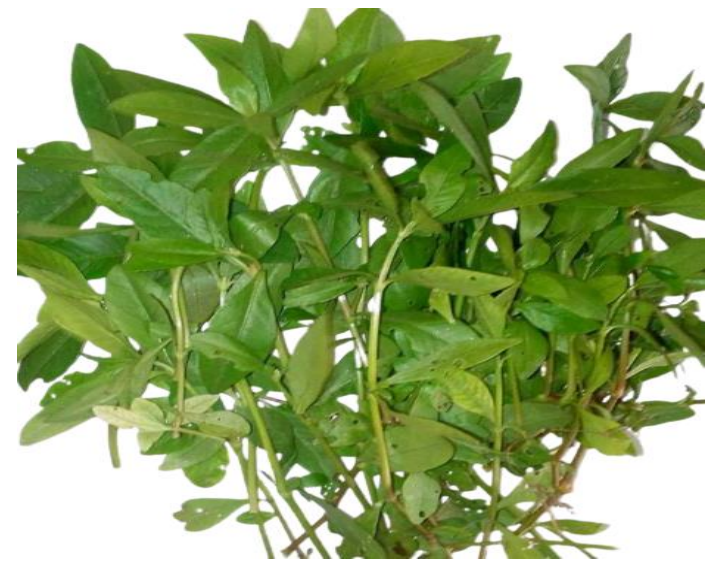

(A)

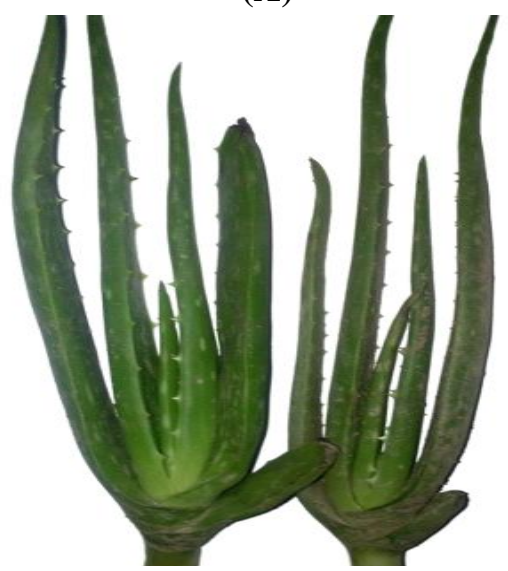

(C)

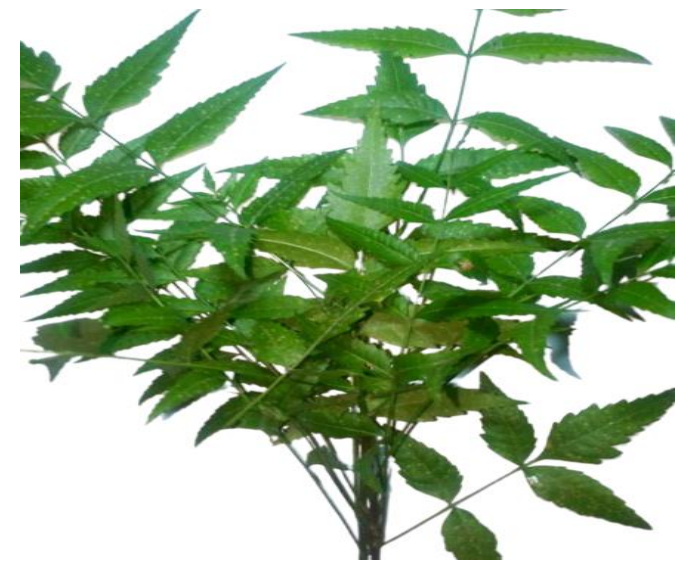

(B)

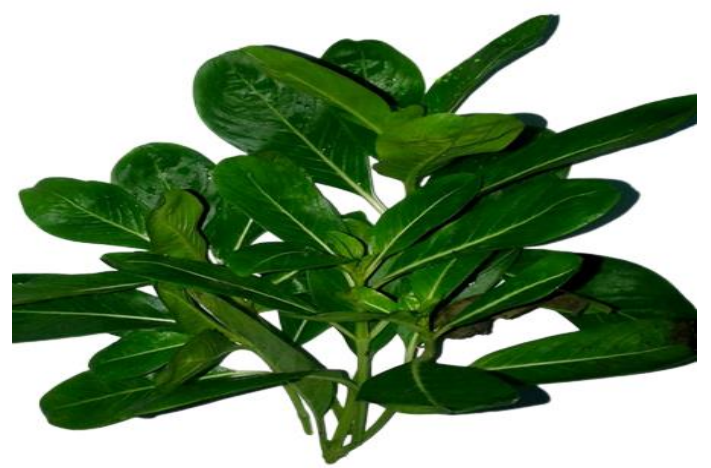

(D)

Figure 1. Speciemen of collected medicinal plants (A) Eclipta prostrata, (B) Azadirachta indica, (C) Aloe vera and (D) Catharanthus roseus.

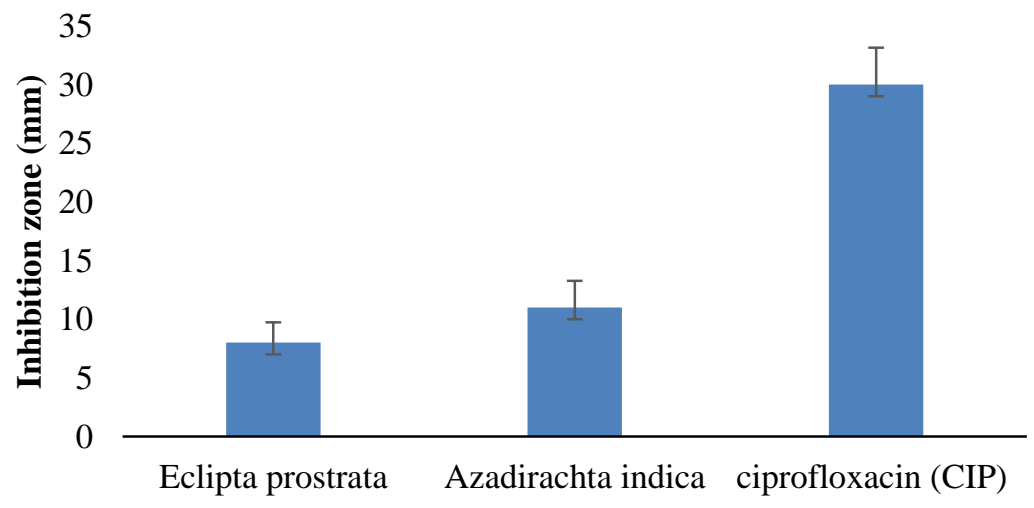

Figure 2A. Comparative bar diagram of inhibition diameter from plant extracts and antibiotic against $\mathrm{E}$. coli. The above bar indicates standard error. 


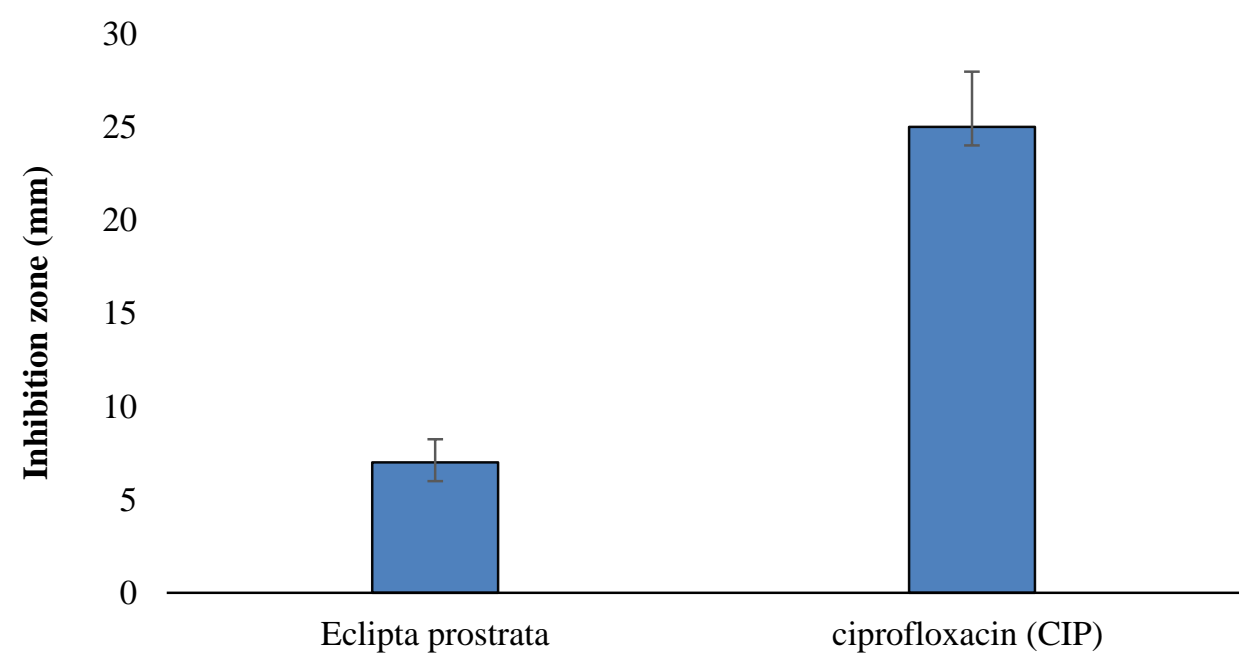

Figure 2B. Comparative bar diagram of inhibition diameter from plant extracts and antibiotic against $S$. aureus. The above bar indicates the standard error.

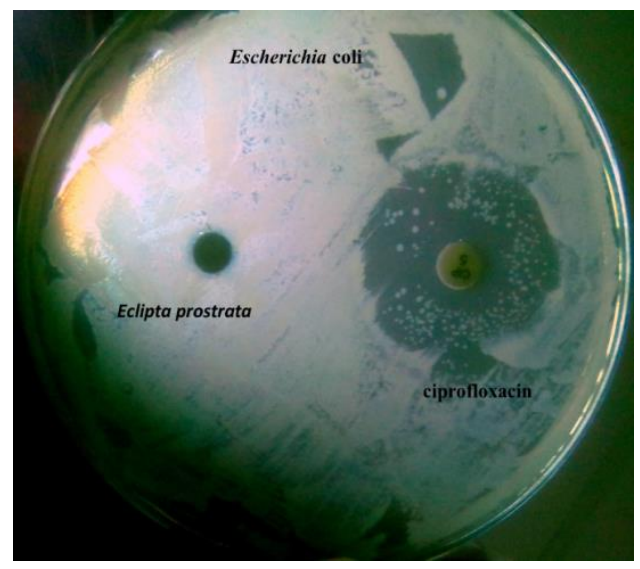

(A)

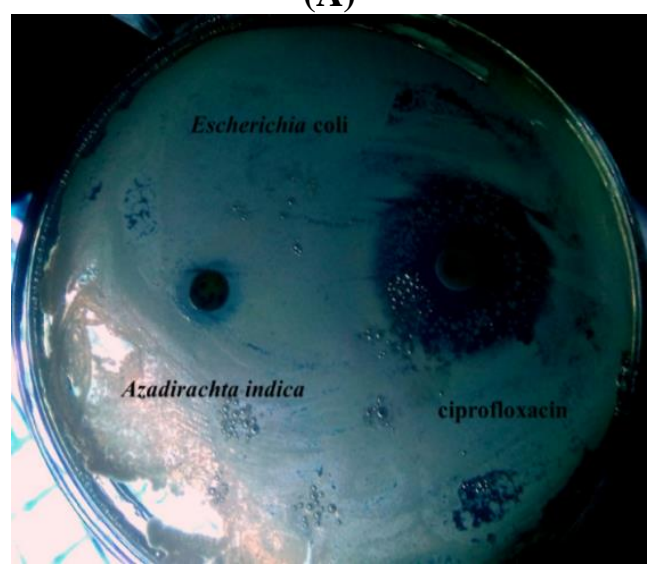

(C)

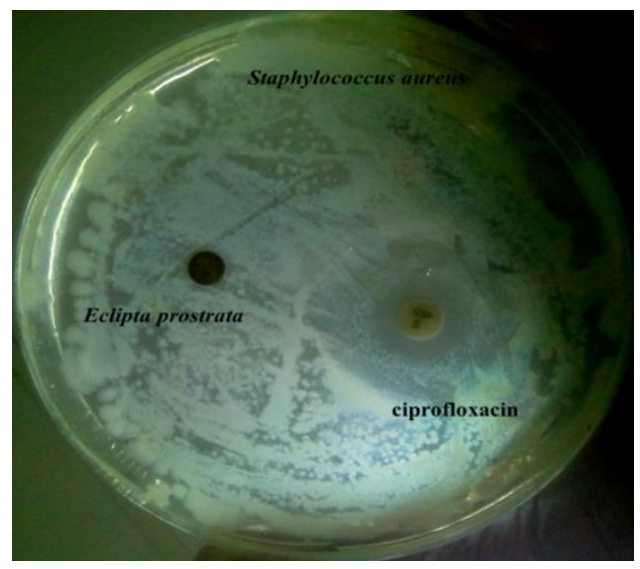

(B)

Figure 3A. Antibacterial activity of Eclipta prostrata and ciprofloxacin (CIP) against Escherichia coli.

Figure 3B. Antibacterial activity of Eclipta prostrata and ciprofloxacin (CIP) against Staphylococcus aureus.

Figure 3C. Antibacterial activity of Azadirachta indica and ciprofloxacin (CIP) against Escherichia coli. 
Table 1. Antibacterial activity data for medicinal plants extract.

\begin{tabular}{|l|l|l|l|l|l|l|}
\hline \multirow{2}{*}{ Bacteria } & \multirow{2}{*}{ Gram -reaction } & \multicolumn{5}{|c|}{ Inhibition zone diameter (mm) } \\
\cline { 3 - 7 } & & E. prostrata & A. indica & A. vera & C. roseus & Antibiotic \\
\hline E. coli & Negative & $8 \pm 1.73$ & $11 \pm 2.27$ & NA & NA & $30 \pm 3.14$ \\
\hline S. aureus & Positive & $7 \pm 1.24$ & NA & NA & NA & $25 \pm 2.96$ \\
\hline \multicolumn{2}{|l|}{ Comments } & ++ & + & - & - & ++ \\
\hline
\end{tabular}

++ indicates antibacterial property for both of the bacterial strain.

+ indicates antibacterial property for only single bacterial strain.

- indicates no antibacterial property for both of the bacterial strain

NA indicates no activity

\section{Conclusions}

Ethanol extract of Eclipta prostrata showed antibacterial activity against Escherichia coli and Staphylococcus aureus; whereas Azadirachta indica showed antibacterial activity against Escherichia coli only. Aloe vera and Catharanthus roseus did not show antibacterial activity against these subjected pathogens. Extract of Eclipta prostrata, Azadirachta indica, Aloe vera and Catharanthus roseus plants did not show any binding affinity to isolated DNA of human cheek cells. From this experimental result, E. prostrata and A. indica may provide an authentic basis to search for a new drug that will be used infectious ailments while remaining plant materials subjected to experiment will be investigated further for both extraction methodologies and antibacterial activities.

\section{Acknowledgements}

Authors would like to thank Research Cell, University of Barishal for financial support. Furthermore authors are grateful to material chemistry laboratory, Department of Chemistry, Shahjalal University of Science and Technology for giving facilities of antibacterial test and thankful to Popular Diagnostic Centre and Hospital, Sylhet for supplying pathogenic bacterial colony.

\section{Conflict of interest}

None to declare.

\section{References}

Adebanjo AO, CO Adewama and EE Essein, 1983. Anti-infective agents of higher plants. Proceedings of an international symposium of Medicinal plants. $5^{\text {th }}$ edition, University of Ife, Nigeria, pp. 152-158.

Ahmad I and AZ Beg, 2001. Antimicrobial and phytochemical studies on 45 Indian medicinal plants against multi-drug resistant human pathogens. J. Ethnopharmacol., 74: 113-123.

Ahmed ZU, ZNT Begum, MA Hassan, M Khondker, SMH Kabir, M Ahmad, ATA Ahmed, AKA Rahman and EU Haque. (Eds) 2008-2009. Encyclo. of Flora and Fauna of Bangladesh. Asiatic Society of Bangladesh, Dhaka. Vols. 6-10.

Alam M and M Haider, 2018. Ethnomedicinal plants used by the Khasia Community people in Moulvibazar district of Bangladesh. International Journal of Ethnobiology \& Ethnomedicine, 5: 1-6.

Bell SM, JN Pham and IW Carter, 2009. Antibiotic Susceptibility Testing by the CDS Method, 5th Ed.

Bhalodia NR and VJ Shukla, 2011. Antibacterial and antifungal activities from leaf extracts of Cassia fistula: an ethnomedicinal plant. J. Adv. Pharm. Technol. Res., 2: 104-109.

Brandi G, G Amagliani, GF Schiavano, DM Santi and M Sisti, 2006. Activity of Brassica oleracea leaf juice on foodborne pathogenic bacteria. J. Food Prot., 69: 2274-2279.

Cagri-Mehmetoglu, A, A Sowemimo and M Venter, 2017. Evaluation of antibacterial activity and phenolic contents of four nigerian medicinal plants. Int. J. Food Process. Technol., 4: 12-21.

Das PR, MT Islam, MN Mostafa and M Rahmatullah, 2013. Ethnomedicinal plants of the Bauri tribal community of Moulvibazar District, Bangladesh. Anc. Sci. Life, 32: 144-159.

Garbieri TF, DT Brozoski, TJ Dionisio, CF Santos and LT Neves, 2017. Human DNA extraction from whole saliva that was fresh or stored for 3, 6 or 12 months using five different protocols. J. of Appl. Oral Sci., 25: $147-158$.

Hossain U and O Rahman, 2018. Ethnomedicinal uses and informant consensus factor of medicinal plants in Barishal district, Bangladesh. Bangladesh J. Plant Taxon., 25: 241-255. 
Islam M, MA Amin, MMA Siddiqi, S Akter, S Haque, N Sultana and AMS Chowdhury, 2012. Isolation of quercetin-3-o-beta-d-glucopyranoside from the leaves of Azadirachta indica and antimicrobial and cytotoxic screening of the crude extracts. Dhaka Univ. J. Sci., 60: 11-14.

Kaisar MA, MS Rahman, MZ Rahman, CM Hasan and MA Rashid, 2011. A Review on Phytochemicals from Some Medicinal Plants of Bangladesh. J. Pharm. Nutr. Sci., 1: 87-95.

Kamali $\mathrm{HH}$ and A Myel, 2010. Antibacterial activity and phytochemical screening of ethanolic extracts obtained from selected Sudanese medicinal plants. Curr. Res J. Bio. Sci., 2: 143-146.

Kelmanson JE, AK Jager and SJ Van, 2000. Medicinal plants with anti-bacterial activity. J. Ethnopharmacol., 69: 241-246.

Lalitha P, KA Arathi, K shubashini, S Hemaltha and P Jayanthi, 2010. Antimicrobial activity and phytochemical screening of an ornamental Foliage Plant, Pothos aurea (Linden exandre). Int. J. of Chem., 1: 63-71.

Meghla NS, M Hossain, B Alam, LR Paul, N Sultana, AK Das and MB Lijon, 2016. Evaluation of some medicinal plants against Escherichia coli, Salmonella spp. and Staphylococcus aureus. Int. J. Nat. Soc. Sci., 3: 25-31.

Molla MTH, MS Ahsan, MT Alam and ME Haque, 2010. Antibacterial activity in the leaves of seven bitter medicinal plants of Bangladesh. Journal of Bio-science, 18: 128-133.

Moussaoui $\mathrm{F}$ and T Alaoui, 2016. Evaluation of antibacterial activity and synergistic effect between antibiotic and the essential oils of some medicinal plants. Asian Pac. J. Trop. Biomed., 6: 32-37.

Natarajan D, BS John, K Srinivasan, N Nagamurugan, C Mohanasundhari and G Perumal, 2005. Anti-bacterial activity of Euphorbia fusiforms: a rare medicinal herb. J. Ethnopharmacol., 102: 123-126.

Prasad KS, LS Kumar, SC Shekar, M Prasad and HD Revanasiddappa, 2011. Oxovanadium complexes with bidentate N, O ligands: synthesis, characterization, DNA binding, nuclease activity and antimicrobial studies. Chem. Sci. J., 12: 1-10.

Rahman MS and MA Rashid, 2008. Antimicrobial activity and cytotoxicity of Eclipta prostrata. Orient. Pharm. Exp. Med., 8: 47-52.

Ramachandran E, P Kalaivani, R Prabhakaran, M Zeller, JH Bartlett, P Adero, OTR Wagner and K Natarajan, 2012. Synthesis, characterization, crystal structure and DNA binding studies of Pd-(II) complexes containing thiosemicarbazone and triphenylphosphine/triphenylarsine. Inorganica Chimica Acta, 385: 94-99.

Ripa FA, L Nahar, A Fazal and MH Khatun, 2012. Antibacterial and phytochemical evaluation of three medicinal plants of Bangladesh. Int. J. Pharm. Sci. Res., 3: 788-792.

Sen A and A Batra, 2012. Evaluation of antimicrobial activity of different solvent extracts of medicinal plant Melia Azedarach L. Int. J. Curr. Pharm. Res., 4: 67-73.

Suhag MH, KM Haque, B Ahmed and M Younus, 2014. Antibacterial activity and DNA interaction of the $\mathrm{Pd}(\mathrm{bpy})\left(\mathrm{ONO}_{2}\right)_{2}$ coordination complex. SUST J. of Sci. and Tech., 21: 16-23.

Uddin N, A Rahman, NU Ahmed, S Rana, R Akter and AMMA Chowdhury, 2010. Antioxidant, cytotoxic and antimicrobial properties of ethanol extract. Int. J. Biol. Med. Res., 1: 341-346.

Uddin M, MK Arefin, MF Alam, G Kibria, SL Podder and MA Hasan, 2017. Knowledge of ethnomedicinal plants and informant consensus in and around Lawachara national park. J. Asiat. Soc. Bangladesh Sci., 43: 101-123.

Valle DL, JI Andrade, JJM Puzon, EC Cabrera and WL Rivera, 2015. Antibacterial activities of ethanol extracts of philippine medicinal plants against multidrug-resistant bacteria. Asian Pac. J. Trop. Biomed., 5: 930-937.

Valli G, M Murugalakshmi and P Mareeswari, 2014. Evaluation of antiinflammatory, analgesic and DNA binding studies of manjanathi fruit extract. Int. J. Res. Pharm. Chem., 4: 61-66.

WHO, 2001. General Guidelines for Methodologies on Research and Evaluation of Traditional Medicine. Geneva, Switzerland, p. 1.

Widjaja EA and RN Lester, 1978. Morphological, chemical \& anatomical analysis of Amorphophallus campanulatus tuber. Reinwadtia, 10: 271-280. 